\title{
Paraoxonase 155 and 192 Gene Polymorphisms in an Egyptian Population with Diabetic Complications
}

Mohamed Abdel-Halem Helaly ${ }^{1}$, Ehab El-Said Abdel-Khalek ${ }^{1}$, Hala A. Abdel-Hafez ${ }^{1}$, Eman Fathi Ibrahem², Ahmed Wafa Soliman ${ }^{3}$, Eid Mohamed Daoud ${ }^{3}$, Zakaria Fawzy Lotfy ${ }^{4}$

\author{
${ }^{1}$ Mansoura University, Department of Inter- \\ nal Medicine \\ ${ }^{2}$ Cairo University Department of Internal \\ Medicine
}

${ }^{3}$ Mansoura University, Department of Cardiology

${ }^{4}$ Mansoura University, Department of Clinical Pathology

Eur J Basic Med Sci 2013;3(1): 9-16

Received: 02-03-2013

Accepted: 15-05-2013

Correspondence (Yazıșma Adresi): Mohamed A. Helaly, Internal Medicine department, Specialized Medical Hospital, B.O.Pox 35516,

Al-Gomhoria Street, , Mansoura, Egypt.

E-mail: helaly70@yahoo.com

\begin{abstract}
Type 2 diabetes mellitus is the most common type of diabetes worldwide with serious macro- and microvascular complications. It is a polygenic disease characterized by interaction of environmental and genetic factors. The paraoxonase 1 gene (PON1) 55 and 192 polymorphisms have been reported to be associated with type 2 diabetes and its complications. Our aim is to study the PON1 55,192 gene polymorphisms and enzyme activity in type 2 diabetic Egyptian population with complications. 100 type 2 diabetic patients with complications (34 with cardiac and 66 with microvascular complications (neuropathy, retinopathy and/or nephropathy). This was in addition to 100 healthy control subjects of matched age and sex were taken. PON1 55 L/M and 192 Q/R gene polymorphisms and PON1 enzyme activity serum levels were detected. The LL genotype of PON1 55 polymorphism and QR and QQ genotypes of PON1 192 polymorphism were more frequent among the patients with diabetic complications. The PON1 enzyme activity levels were lower among the diabetic patients than in control subjects. PON1 55 and 192 polymorphisms and enzyme activity seems to be related to diabetic complications in an Egyptian type 2 diabetic patients.
\end{abstract}

Key Words: Diabetes, Complications, Paraoxonase 1, Polymorphisms, Egyptian

Diyabetik Komplikasyonları Olan Mısır'lılarda Paraoksonaz1'in 55 ve 192 Gen Polimorfizmleri

\section{ÖZET}

Tip 2 diyabetes mellitus ciddi makro ve mikrovasküler komplikasyonlar ile dünya çapında diyabetin en sık görülen tipidir. Çevresel ve genetik faktörlerin etkileșimi ile karakterize poligenik bir hastalıktır. Paraoksonaz 1 geni (PON1) 55 ve 192 polimorfizmlerinin tip 2 diyabet ve komplikasyonları ile ilișkili olduğu bildirilmiștir. Amacımız tip 2 diyabet komplikasyonları olan Misır'lılarda PON1 55, 192 gen polimorfizmleri ve enzim aktivitesini incelemektir. Çalıșmaya komplikasyon gelișmiș olan tip 2 diyabetli 100 hasta dahil edildi (34'ü kardiyak, 66'sı mikrovasküler komplikasyonlu (nöropati, retinopati ve / veya nefropati)) Ayrıca kontrol grubu olarak yaș ve cinsiyet uyumlu 100 sağlıklı çalıșmaya alınmıștır. PON1 $55 \mathrm{~L} / \mathrm{M}$ ve $192 \mathrm{Q} / \mathrm{R}$ gen polimorfizmleri ve serum PON1 enzim aktivitesi düzeyleri tespit edildi. PON1 55 polimorfizmi'nin 
LL genotipi ve PON1 192 polimorfizminin $Q R$ ve $Q Q$ genotipleri diyabetik komplikasyonları olan hastalarda daha sıktı. PON1 enzim seviyeleri ise kontrol grubuna göre diyabetik hastalarda daha düşüktü. PON1 55 ve 192 polimorfizmleri ve enzim aktivitesinin tip 2 diyabetik Misir'lı hastalarda diyabetik komplikasyonlarla ilișkili olduğu görülmektedir.

Anahtar kelimeler: Diabet, Komplikasyonlar, Paraoksonase 1, Polimorfizmler, Misir

\section{INTRODUCTION}

Type 2 diabetes mellitus (DM) is a multifactorial disease characterized by both clinical and genetic heterogeneity (1). Chronic complications of type 2 diabetes can be classified as macrovascular (coronary artery disease (CAD), peripheral artery disease, and cerebrovascular disease) and microvascular (diabetic nephropathy, retinopathy, and neuropathy) (2). Human serum paraoxonase (PON) enzyme was characterized as an organophosphate hydrolase. In addition to its role in hydrolyzing organophosphorus compounds, PON has been shown to play an important role in lipid metabolism and thus in cardiovascular disease and atherosclerosis (3). PON 1 enzyme is a calciumdependent antioxidant glycoprotein, is synthesized in the liver and secreted into the plasma, where it is associated with high density lipoproteins (HDL). PON1 enzyme is implicated in lipid metabolism and in the elimination of carcinogenic lipid-soluble radicals (4). PON1 protects both low density lipoprotein (LDL) and high density lipoprotein (HDL) from oxidation. It prevents the formation of oxidized LDL (ox-LDL) and inactivates LDL-derived oxidized phospholipids and prevents oxidation of HDL phospholipids (5). The human PON1 gene has been mapped to $7 q 21.3(6)$. The most familiar polymorphisms of the PON1 gene are the glutamine/arginine substitution $(\mathrm{Q} / \mathrm{R})$ at codon 192 and the leucine/metionine substitution $(\mathrm{L} / \mathrm{M})$ at codon 55 (7). There is a controversy regarding the association of PON1 gene polymorphisms with diabetic complications, some of the studies had suggested that there is an association (8), while others failed to show an association (9). Although some of these controversial results can be explained by factors such as the type of population studied, dietary habits, and differences in study design.

We aimed to evaluate the relationship between the macrovascular (coronary artery disease) and microvascular complications of type 2 DM, PON1 gene polymorphisms, and PON1 enzyme activity in an Egyptian population.

\section{MATERIAL and METHODS}

\section{Study population}

A total of 100 type 2 diabetic patients with complications were selected from the outpatient and inpatient sections of Diabetes and Cardiology departments, Specialized Medical Hospital, Mansoura University. This is in addition to 100 healthy age and sex matched control subjects. Informed written consents were given by all patients and control subjects. They undergone full clinical examination; including measurement of blood pressure, body mass index $(\mathrm{BMl}=$ body weight $(\mathrm{kg}) \div$ height $(\mathrm{m}) 2$. This is in addition to ECG, and doppler flow mapping of the carotid and peripheral arterial system. Diagnostic coronary angiography was done for all patients for diagnosis of coronary artery disease (CAD). All patients and control subjects were subjected to thorough history taking, and they were questioned regarding hypertension, macro and microvascular complications of DM. Assessment of the patients for the presence of diabetic microvascular complications was done as the following; diabetic peripheral neuropathy was diagnosed by a history of glove and stoke hypothesia, dysethia, or pain in limbs. We confirmed this by absence of pain sensation using the Symmes-Weinstein monofilament (10), loss of vibration sense over malleoli using tuning fork and/or loss of ankle reflex (11); and electroneuromyography was done in doubtful cases (12). Autonomic neuropathy was diagnosed from history of orthostasis, prolonged diarrhea or constipation or the presence of erectile dysfunction. We confirmed this by finding resting tachycardia, postural hypotension and lack of R-R variation on ECG during Valsalva maneuver (11). Assessment for diabetic retinopathy was done by examination of the fundus of the eye bilaterally in fully dilated pupils using the ophthamoscope. Diagnosis was made when we found retinal hemorrhage, exudates, retinal microaneurysms, new vessels and/or vitreous hemorrhage (13). We planned to do renal biopsy for diagnosis of diabetic nephropathy (14); but unfortunately, it cannot be done. So, we depend on detection of urinary albumin / creatinine ratio in morning spot urine samples for diagnosis of diabetic nephropathy, if it is more than 30 $\mathrm{mg} / \mathrm{gm}$ the diagnosis of albuminuria was established (15). Laboratory work up was done for all patients and control subjects including; fasting and post-prandial plasma glucose, total cholesterol, low density lipoprotein (LDL), high density lipoprotein (HDL), triglyceride (TG), serum creatinine and glycosylated hemoglobin. This is in addition to detection of paraoxonase 1 enzyme activity in the 
serum by the following method: The activity of paraoxonase was assayed using paraoxon (Sigma, St. Louis, MO) as a substrate. The assay buffer was prepared from $0.132 \mathrm{M}$ Tris- $\mathrm{HCl}, \mathrm{pH}$ 8.5, and1.32 mM CaCl2. For each set of assays, $6 \mathrm{mM}$ freshly prepared paraoxon substrate solution (120 mM paraoxon in acetone diluted with 0.132 $\mathrm{mM}$ Tris- $\mathrm{HCl}$ ) was used. The assay tube contained 152 Tris buffer, 8 serum (1:2 diluted with water) and 40 of $6 \mathrm{mM}$ paraoxon. The reaction was initiated at $37.8 \_\mathrm{C}$ by the addition of the substrate solution, and absorbance was continuously monitored at $405 \mathrm{~nm}$. A molar extinction coefficient of 18050 was obtained and used to calculate activity, and units were expressed as micromoles of paraoxon hydrolyzed per minute (16).

PON1 L55M and Q192R polymorphisms were detected by the following method: PON $1-55 \mathrm{~L}>\mathrm{M}$ gene polymorphism typing by restriction fragment length polymorphism (RFLP): The PON 1-55 L>M single nucleotide polymorphism (SNP; rs854560) in the coding region of the PON 1 gene (7q21.2) was genotyped using the PCR-RFLP method previously reported by Hasselwander et al. 1999 (17). DNA was extracted from whole venous blood using the EZNA blood DNA extraction kit (Omega bio-tek, Norcross, GA, Lot No. D 3392-01). Genomic DNA was amplified using PCR with different primers (forward and reverse). The sequences of primers (Biolegia) used were as follows: forward primer, 5'GAA GAG TGA TGT ATA GCC CCA G 3'; and reverse primer, 5 'TTT AAT CCA GAG CTAATG AAA GCC 3'. The reaction volume was $25 \mu \mathrm{L}: 5 \mu \mathrm{L}$ DNA at $100 \mathrm{ng} /$ $\mu \mathrm{L}, 15.0 \mu \mathrm{L}$ DreamTaq Green mater mix (Fermentas, Lot
No.39428), $0.5 \mu \mathrm{L}$ of each primer ( $25 \mathrm{pmoL} / \mu \mathrm{L})$, and 4.0 $\mu \mathrm{L} \mathrm{H} 2 \mathrm{O}$. Reaction conditions were carried out in a thermocycler PTC-100 (Bio-Rad) at $95{ }^{\circ} \mathrm{C}$ for 4 minutes followed by 32 cycles of $95{ }^{\circ} \mathrm{C}$ for 60 seconds, $59{ }^{\circ} \mathrm{C}$ for 60 seconds, and $72{ }^{\circ} \mathrm{C}$ for 60 seconds. A total of $10 \mu \mathrm{L}$ of PCR products was resolved in $2 \%$ agarose gel to check the PCR products at the 170-bp fragment. RFLP analysis was performed using Nlalll enzyme (Clinilab) in $15.5 \mu \mathrm{L}$ total volume by mixing $10 \mu \mathrm{L}$ of PCR products $+0.5 \mu \mathrm{L}$ of Nlalll restriction enzyme $+5.0 \mu \mathrm{L}$ of BSA buffer $(0.1 \mu \mathrm{g} / \mu \mathrm{l}$ final concentration). The mixture was incubated at $37{ }^{\circ} \mathrm{C}$ for overnight. DNA fragments were resolved in $5 \%$ agarose gels and ethidium bromide staining followed by ultraviolet visualization. Digestion of PCR products yielded 126 + 44 bp fragments $(M M)$, a single 170-bp fragment (LL), and $170+126+44$ bp fragments (LM). PON $1-192 \mathrm{Q}>\mathrm{R}$ gene polymorphism typing by restriction fragment length polymorphism (RFLP): The PON 1 -192 Q>R single nucleotide polymorphism (SNP; rs662) in the coding region of the PON 1 gene (7q21.2) was genotyped using the PCRRFLP method previously reported by Hasselwander et al. 1999[17]. Genomic DNA was amplified using PCR with different primers (forward and reverse). The sequences of primers (Biolegia) used were as follows: forward primer, 5'TAT TGT TGC TGT GGG ACC TGA G 3'; and reverse primer, 5'CAC GCT AAA CCC AAA TAC ATC TC 3'. The PCR reaction and cycling was the same as above. A total of $10 \mu \mathrm{L}$ of PCR products was resolved in $2 \%$ agarose gel to check the PCR products at the 99-bp fragment. RFLP analysis was performed using Alw1 enzyme (Clinilab) in $15.0 \mu \mathrm{L}$

Table 1. Comparison of characteristics of diabetic patients and controls in Egyptian population

\begin{tabular}{llll}
\hline Characterictic & Patients $(\mathrm{N}=100)$ & Control $(\mathrm{N}=100)$ & P value \\
\hline Age $($ years $)$ & $54.18 \pm 7.8$ & $53.1 \pm 4.6$ & 0.2 \\
Sex (M/F) & $44 / 56$ & $45 / 55$ & 0.9 \\
BMl $(\mathrm{kg} / \mathrm{m} 2)$ & $32.2 \pm 3.4$ & $23.0 \pm 1.9$ & 0.001 \\
SBP $(\mathrm{mmgh})$ & $146 \pm 14$ & $122 \pm 10.3$ & 0.001 \\
DBP $(\mathrm{mmgh})$ & $90.55 \pm 7.5$ & $73.5 \pm 8.2$ & 0.001 \\
FBG $(\mathrm{mg} / \mathrm{dl})$ & $170.9 \pm 37.6$ & $74.99 \pm 9.1$ & 0.001 \\
PPBG (mg/dl) & $242.9 \pm 51.7$ & $126.6 \pm 9.7$ & 0.001 \\
HbA1c $(\%)$ & $8.2 \pm 1.2$ & $5 \pm 0.4$ & 0.001 \\
Cholesterol $(\mathrm{mg} / \mathrm{dl})$ & $199.1 \pm 38.1$ & $129.9 \pm 15.6$ & 0.001 \\
LDL $(\mathrm{mg} / \mathrm{dl})$ & $122.9 \pm 14.6$ & $75.4 \pm 11.1$ & 0.001 \\
HDL $(\mathrm{mg} / \mathrm{dl})$ & $39.6 \pm 3.5$ & $46.2 \pm 4.2$ & 0.001 \\
TG $(\mathrm{mg} / \mathrm{dl})$ & $170.6 \pm 22.5$ & $124.7 \pm 17.1$ & 0.001 \\
Creatinine & $1.2 \pm 0.2$ & $0.9 \pm 0.2$ & 0.001 \\
PON1 activity $(\mu \mathrm{mol} / \mathrm{min} / \mathrm{l})$ & $89.1 \pm 11.4$ & $239.6 \pm 49.3$ & 0.001
\end{tabular}

BMI: body mass index, DBP: diastolic blood pressure, FBG: fasting blood glucose, HbA1c: glycosylated hemoglobin, HDL: high density lipoprotein, LDL: low density lipoprotein, PON1: paraoxonase -1, PPBG : post-prandial blood glucose, SBP: systolic blood pressure, TG: triglyceride, $\mu \mathrm{mol} / \mathrm{min} / \mathrm{l}: \mathrm{micromole} / \mathrm{minute} /$ litre. 
Table 2. PON1 55 and 192 polymorphism genotypes and allele frequencies in patients and control groups

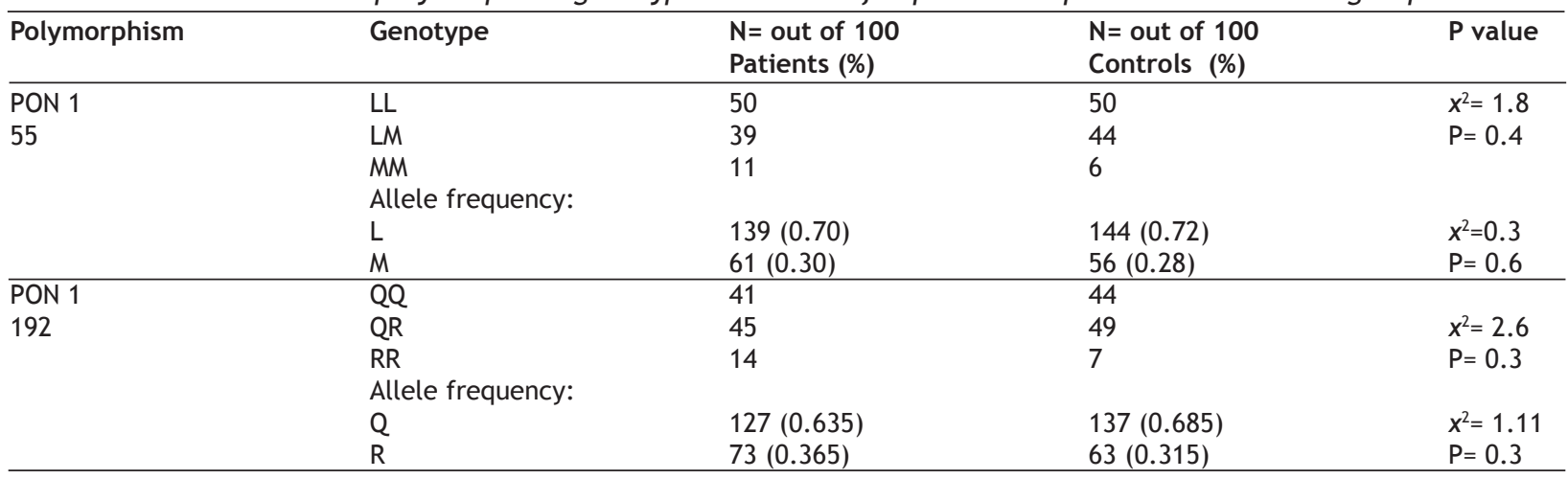

total volume by mixing $10 \mu \mathrm{L}$ of PCR products $+5.0 \mu \mathrm{L}$ of Alw1 restriction enzyme. The mixture was incubated at $37{ }^{\circ} \mathrm{C}$ for overnight. DNA fragments were resolved in $5 \%$ agarose gel, visualized by UV after ethidium bromide staining. Digestion of PCR products yielded $66+33 \mathrm{bp}$ fragments (RR), a single 99-bp fragment (QQ), and $99+$ $66+33$ bp fragments (QR).

Statistical analysis was performed by SPSS version 16 . Continuous variables were expressed as mean \pm standard deviations and were compared by Student's t-test for two groups or ANOVA for more than two groups. Qualitative data were compared between groups by the Chi-square test. Allele frequencies were estimated by the gene counting method, and Hardy-Weinberg equilibrium was checked by the Chi-square test. A value of $p<0.05$ was considered to represent a statistically significant result.

\section{RESULTS}

The patients in our study were age and sex matched with the control subjects. The patients had a significantly higher levels of BMI, systolic and diastolic blood pressures (SBP and DBP respectively), fasting, post-prandial plasma glucose, glycosylated hemoglobin, total cholesterol, LDL, TG, and creatinine. However, the patients had significantly lower values of PON1 activity and HDL than the control subjects as shown in table 1. Regarding the PON1 55 and 192 polymorphisms; the allele frequencies were 0.70 for the $L$ allele and 0.635 for the $Q$ allele in patients, and 0.72 for $L$ allele and 0.685 for the $Q$ allele in the control group. There is no significant difference between them as shown in table 2. Also, the cases were found to be in Hardy-Weinberg equilibrium, for both the PON1 55 and 192 polymorphisms. We had 34 diabetic cardiac cases, in addition to 66 diabetic cases with microvascular complications. The genotypes LL and QR frequently

Table 3. Comparison of PON1 55 and 192 genotypes with diabetic complications

\begin{tabular}{|c|c|c|c|c|c|c|c|}
\hline \multirow{2}{*}{$\begin{array}{l}\text { Complications } \\
\text { ( } \mathrm{N}=\text { of patients) }\end{array}$} & \multicolumn{6}{|c|}{ PON 155 genotype } & \multirow[t]{2}{*}{ P value } \\
\hline & LL & (\%) & LM & (\%) & MM & (\%) & \\
\hline Diabetic cardiac group (34) & 17 & (50) & 12 & $(35.3)$ & 5 & (14.7) & 0.7 \\
\hline \multirow{3}{*}{$\begin{array}{l}\text { Diabetics with microvascular } \\
\text { Complications (66) }\end{array}$} & 33 & (50) & 27 & (40.9) & 6 & (9.1) & 0.7 \\
\hline & \multicolumn{6}{|c|}{ PON 1192 genotype } & \\
\hline & $\mathrm{QQ}$ & (\%) & QR & (\%) & RR & (\%) & \\
\hline Diabetic cardiac group (34) & 14 & $(41.1)$ & 16 & (47.1) & 4 & (11.8) & 0.9 \\
\hline $\begin{array}{l}\text { Diabetics with microvascular } \\
\text { Complications }(66)\end{array}$ & 27 & $(40.9)$ & 29 & (43.9) & 10 & (15.2) & 0.9 \\
\hline
\end{tabular}


Table 4. Serum PON1 activity in diabetic patients with complications and controls according to $L / M 55$ and $Q / R$ 192 genotypes

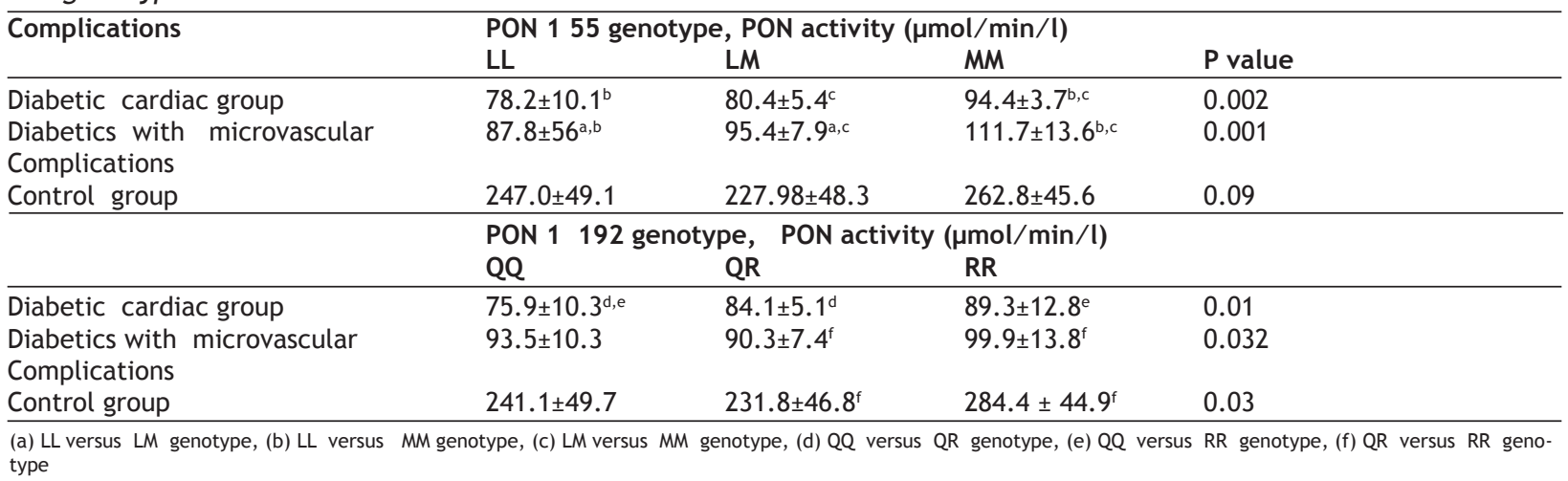

showed the microvascular and macrovascular complications of type $2 \mathrm{DM}$, however, no significant differences for the $L$ and $M$ alleles were found between the groups. The $\mathrm{Q}$ and $\mathrm{R}$ alleles in both groups showed no significant differences in frequency as shown in table 3 . In the diabetic cardiac group and in the diabetic group with microvascular complications, the PON1 activity was significantly higher in MM genotype of PON1 55 polymorphism in comparison to LL and LM genotypes. Moreover, in the diabetic group with microvascular complications, it is significantly higher in LM in comparison to LL genotype. In the diabetic cardiac group; the PON1 activity was significantly lower in QQ genotype of PON1 192 polymorphism than in $\mathrm{QR}$ and RR genotypes. Moreover, the PON1 activity was significantly lower in $Q R$ than in RR genotype in the diabetic group with microvascular complications and also in the control group as shown in table 4 .

\section{DISCUSSION}

PON1 polymorphisms differ with ethnic background, such that the incidence of the RR genotype is $42.7 \%$ in Japan, about $20 \%$ in Caucasians, and 33\% in China (18). In our study, the incidence of the RR genotype was $7 \%$ in control group. The frequency of the $M$ allele was $6.9 \%$ in Japan, $15 \%$ in Caucasians, and $28 \%$ in the control group in our study. The $\mathrm{R}$ allele is more frequent in Japanese and Chinese patients with CAD than in Caucasians (19). The QR polymorphism has been reported to be related to the development of CAD. The frequency of the R allele was increased in patients with CAD with respect to the controls. In addition, type 2 diabetic patients with LL geno- type were found to have an increased risk of CAD (20). Nonetheless, a recent study has revealed that RR genotype may be associated with less production of reactive oxygen metabolites in Japanese subjects (21). Moreover, another recent study have suggested that Paraoxonase-1 is not associated with coronary artery calcification in type 2 diabetes but in this study all patients were asymptomatic for coronary artery disease (22). In our study, the RR genotype was found in $11.8 \%$ of the diabetic cardiac group, and in $7 \%$ of the control subjects. However, the $\mathrm{QQ}$ and $\mathrm{QR}$ genotypes were more frequent in the diabetic cardiac group ( $41.1 \%$ and $47.1 \%$ respectively). It is worth mentioning that PON1 55 genotype was reported to be associated a 1.78- fold increase in the risk of ischemic stroke in Turkish population $(23,24)$ with the highest PON activities detected in the LL and RR genotypes (24). In our study, the LL genotype was more common in the diabetic cardiac group but it had no statistically significant difference from other genotypes $L M$ and $M M$. On the other hand, the $Q R$ and $Q Q$ genotypes were more prevalent than the RR genotype in the diabetic cardiac group, but there was no statistically significant difference between them.

The previous studies had suggested that the combined genotypes of RR/LL increase the risk of $\operatorname{CAD}(25,26)$ and it has been reported that the QR genotype was the most common in patients with CAD [25]. A positive family history of CAD was found to be associated with the $R$ allele (27). Another study indicated that the RR genotype is significantly associated with CAD in a north Indian population (28). This does not agree with our study, in which the RR genotype is the least prevalent in the diabetic 
cardiac group, and the QQ and QR genotypes were more prevalent. The cause of this difference may because our study was done on an Egyptian population with different ethnic and genetic background from other nations in other countries like India and Turkey. A strong relationship between the LL genotype and the development of diabetic retinopathy has been reported (29) and the L allele was reported to be associated with retinopathy (30). This agrees with our study in which $L L$ and $Q R$ genotypes were more prevalent among diabetic patients with microvascular complications, but still with no statistically significant difference from other genotypes. The $\mathrm{Q}$ allele is thought to have an important role in the risk of developing membranoproliferative glomerulonephritis and may also be associated with the poor prognosis of this disease in children (31). The lower PON1 activity determined in type 2 diabetic patients has been associated with micro- and macrovascular complications of DM (32). It has been reported that PON1 activity is decreased in diabetic nephropathy and neuropathy $(33,34)$. This comes in agreement with our study in which the cases had a significantly lower value of PON1 activity than in the control group. Moreover, we found that the enzyme activity differs with different PON1 polymorphisms, being lower in $\mathrm{LL}$ and $\mathrm{QQ}$ genotypes, intermediate activities in $L M$ and $Q R$ genotypes, and the highest activities in $M M$ and RR genotypes which may indicate that $L L, Q Q$ and $Q R$ genotypes may be related to diabetic complications, and on the contrary the MM and RR genotypes may be protective in Egyptian population. However, other studies had found that the relations of the genotypes to the enzyme activity were different from our study which may be due to different populations studied (35). Our study had some limitations; the most important is the small sample size because of financial and logistic reasons. In addition to that, we did not found in the literature any comment about the PON1 polymorphisms in an Egyptian population. Another study on larger number of Egyptian population is needed to confirm our results.

\section{Acknowledgment}

We thank to professor Abdel-Hady Al-Gelany for his help in statistical analysis of the data in our study.

\section{REFERENCES}

1. Groop LC. The molecular genetics of non-insulin-dependent diabetes mellitus. J Intern Med 1997; 241: 95-101.

2. Potluri R, Purmah Y, Dowlut M, Sewpaul N, Lavu D. Microvascular diabetic complications are more prevalent in India compared to Mauritius and the UK due to poorer diabetic control. Diabetes Res Clin Pract 2009; 86: 39-40.

3. Mackness B, Durrngton PN, Mackness MI. The paraoxonase gene family and coronary heart disease. Curr.Opin. Lipidol 2002; 13: 357-62.

4. Mackness B, Mackness MI, Arrol S, Turkei W, Durrington PN. Effect of the human serum paraoxonase 55 and 192 genetic polymorphism on the protection by high density lipoprotein against low density lipoprotein oxidative modification. FEBS Lett 1998; 423: 57-60.

5. Senti M, Tomas M, Marrugat J, Elosua R. Paraoxonase 1-192 polymorphism modulates the nonfatal myocardial infarction risk associated with decreased HDLs. Arterioscler Thromb Vasc Biol 2001; 21: 415.

6. Primo-Parmo SL, Sorenson RC, Teiber J, La Du BN. The human serum paraoxonase/arylesterase gene (PON1) is one member of a multigene family. Genomics 1996; 33: 498507.

7. Adkins S, Gan KN, Mody M, La Du BN. Molecular basis for the polymorphic forms of human serum paraoxonase/arylesterase: glutamine or arginine at position 191, for the respective A or B allozymes. Am J Hum Genet 1993; 52: 598-608.

8. Osei-Hyiaman D, Hou L, Mengbai F, Zhiyin R, Zhiming Z, and Kano K. Coronary artery disease risk in Chinese type 2 diabetics: is there a role for paraoxonase 1 gene (Q192R) polymorphism? Eur.J.Endocrinol 2001; 144: 639-44.

9. Arca $M$, Ombres $D$, Montali, Campagna $F$, Mangieri $E$, Tanzilli G, et al. PON1 L55M polymorphism is not a predictor of coronary atherosclerosis either alone or in combination with Q192R polymorphism in an Italian population. Eur J Clin Invest 2002; 32: 9-15.

10. Kamei N, Yamane K, Nakanishi S, Yamashita Y, Tamura T, Ohshita K, et al. Effectiveness of Semmes-Weinstein monofilament examination for diabetic peripheral neuropathy screening. J Diabetes Complications 2005; 19 (1): 47-53.

11. Gries FA, Cameron NE, Low PA, Ziegler D. Textbook of Diabetic Neuropathy. Thieme Medical Publishers 2003. 
12. Rathur HM, Boulton AJ. Recent advances in the diagnosis and management of diabetic neuropathy. J Bone Joint Surg Br 2005; 87 (12): 1605-10.

13. American Diabetes Association: Diabetic retinopathy. Diabetes care 2001; 24 (supl.1): S73-6.

14. Biesenbach $G$, Bodlaj G, Pierninger H, Sedlak M. Clinical versus histological diagnosis of diabetic nephropathy- is renal biopsy required in type 2 diabetic patients with renal disease? QJM 2011; 104 (9): 771-4.

15. KDIGO GN Work Group. KDIGO clinical practice guideline for glomerulonephritis. Kidney inter., Suppl 2012; 2: 139274.

16. Furlong CE, Richter RJ, Seidel SL, Motulsky AG. Role of genetic polymorphism of human plasma paraoxonase/arylesterase in hydrolysis of the insecticide metabolites chlorpyriphos oxon and paraoxon. Am J Human Genet 1988; 43: 230-8.

17. Hasselwander $O$, Savage DA, McMaster D, Loughrey CM, McNamee PT, Middleton D, et al. Paraoxonase polymorphisms are not associated with cardiovascular risk in renal transplant recipients. Kidney Int 1999; 56: 289-98.

18. Ueno $T$, Shimazaki E, Matsumoto $T$, Watanabe $H$, Tsunemi A, Takahashi $Y$, et al. Paraoxonase1 polymorphism LeuMet55 is associated with cerebral infarction in Japanese population. Med Sci Monit 2003; 9: CR208-12.

19. Hu Y, Tian H, Liu R. Gln-Arg192 polymorphism of paraoxonase 1 is associated with carotid intima-media thickness in patients of type 2 diabetes mellitus of Chinese. Diabetes Res Clin Pract 2003; 61: 21-7.

20. Zama T, Murata M, Matsubara Y, Kawano K, Aoki N, Yoshino $H$, et al. A 192Arg variant of the human paraoxonase (HUMPONA) gene polymorphism is associated with an increased risk for coronary artery disease in the Japanese. Arterioscler Thromb Vasc Biol 1997; 17: 3565-9.

21. Kotani K, Tsuzaki K, Sakane N. Paraoxonase-1 Gene Q192R Polymorphism and Reactive Oxygen Metabolites. J Int Med Res 2012; 40(4):1513-8.

22. Mackness B, Marsillach J, Elkeles RS, Godsland IF, Feher $M D$, Rubens MB, et al. Paraoxonase- 1 is not associated with coronary artery calcification in type 2 diabetes: Results from the PREDICT study. Dis Markers 2012; 33(2):101-12.

23. Demirdogen BC, Demirkaya S, Tu“rkanoglu A, Bek S, Arinc E, Adali O. Analysis of paraoxonase 1 (PON1) genetic polymorphisms and activities as risk factors for ischemic stroke in Turkish population. Cell Biochem Funct 2009; 27: 558-67.

24. Kaman D, Ilhan N, Metin K, Akbulut M, Ustundag B. A preliminary study of human paraoxonase and PON 1 L/M55PON 1 Q/R 192 polymorphisms in Turkish patients with coronary artery disease. Cell Biochem Funct 2009; 27: 88-92.

25. Aynacioglu AS, Kepekci Y. The human paraoxonase GlnArgl92 (Q/R) polymorphism in Turkish patients with coronary artery disease. Int J Cardiol 2000; 74: 33-7.

26. Ozkok E, Aydin M, Babalik E, Ozbek Z, Ince N, Kara I. Combined impact of matrix metalloproteinase-3 and paraoxonase 1 55/192 gene variants on coronary artery disease in Turkish patients. Med Sci Monit 2008; 14(10): CR536-42.

27. Gluba A, Pietrucha T, Banach M, Piotrowski G, Rysz J. The role of polymorphisms within paraoxonases (192 Gln/Arg in PON1 and 311Ser/Cys in PON2) in the modulation of cardiovascular risk: a pilot study. Angiology 2010; 61: 157-65.

28. Agrawal S, Tripathi G, Prajnya R, Sinha N, Gilmour A, Bush $L$, et al. Paraoxonase 1 gene polymorphisms contribute to coronary artery disease risk among north Indians. Indian J Med Sci 2009; 63: 335-44.

29. Mackness B, Durrington PN, Abuashia B, Boulton AJ, Mackness MI. Low paraoxonase activity in type II diabetes mellitus complicated by retinopathy. Clin Sci (Lond) 2000; 98: 355-63.

30. Kao YL, Donaghue K, Chan A, Knight J, Silink M. A variant of paraoxonase (PON1) gene is associated with diabetic retinopathy in IDDM. J Clin Endocrinol Metab 1998; 83: 2589-92.

31. Bilge I, Sirin A, Agachan B, Emre S, Sadikoglu B, Yilmaz H, et al. Is paraoxonase 192 gene polymorphism a risk factor for membranoproliferative glomerulonephritis in children? Cell Biochem Funct 2007; 25: 159-65.

32. Tsuzura S, Ikeda Y, Suehiro T, Ota K, Osaki F, Arii K, et al. Correlation of plasma oxidized low-density lipoprotein levels to vascular complications and human serum paraoxonase in patients with type 2 diabetes. Metabolism 2004; 53: 297-302.

33. Abbott CA, Mackness MI, Kumar S, Boulton AJ, Durrington $P N$. Serum paraoxonase activity, concentration, and phenotype distribution in diabetes mellitus and its relationship to serum lipids and lipoproteins. Arterioscler Thromb Vasc Biol 1995; 15: 1812-8.

34. Kopprasch S, Pietzsch J, Kuhlisch E, Graessler J. Lack of association between serum paraoxonase 1 activities and in- 
creased oxidized low-density lipoprotein levels in impaired glucose tolerance and newly diagnosed diabetes mellitus. J Clin Endocrinol Metab 2003; 88: 1711-6.
35. Ergun M, Yurtcu $E$, Demirci $H$, Ilhan M, Barkar V, Yetkin I, et al: PON1 55 and 192 Gene Polymorphisms in Type 2 Diabetes Mellitus Patients in a Turkish Population. Biochem Genet 2011; 49(1-2):1-8. 